\title{
Microwave Individual and Combined Pre-Treatments on Lignocellulosic Biomasses
}

\author{
Shuaib M. Laghari ${ }^{1}$, Muhamad Hasnain Isa ${ }^{2}$, Azmuddin bin Abdullah ${ }^{3}$, \\ Abdul Jabbar Laghari ${ }^{4}$, Hussain Saleem ${ }^{5 *}$ \\ ${ }^{1,2,3}$ Civil Engineering Department, Universiti Teknologi Petronas, 31750 Tronoh, Perak, Malaysia. \\ ${ }^{4}$ Institute of Advanced Research Studies in Chemical Sciences, University of Sindh, Jamshoro, Pakistan. \\ ${ }^{5}$ Department of Computer Science, University of Karachi, Karachi-75270, Pakistan
}

\begin{abstract}
Lignocellulosic Biomass is considered to be the best option for biofuels production, due to the energy and food security concerns comparative to the use of other wastes, but this biomass has limited digestibility due to many factors like particle size, crystallinity of cellulose, lignin content etc. Pre-treatments enhance the digestibility by reducing the effect of these factors. Different pretreatment types exist, but now microwave pretreatment (individual or combined with other pretreatments) is becoming common due to its better results. This paper reviews the advantages of using lignocellulosic biomass in terms of the biofuels obtained from it, common pretreatments applied on it, and the effects of microwave pretreatments (individual and combined) over it.
\end{abstract}

Keywords: - Biomass, Biofuel, Lignocellulose, Microwave, Pretreatment

\section{INTRODUCTION}

The fossil fuels are considered to be the main source of energy today, but there are some concerns regarding their sustainability. Their expected reserves are depleting with the rapid explorations in order to meet the growing energy needs of the world. The pollutants and other extractives from these fuels are also harmful for the environment. Both these considerations demand an energy source, which will be available in abundant quantity and sustainability, and that must also be environmental friendly. For this reason various alternate energy sources are being investigated, which may replace the fossil fuels economically. The World nations are focusing to alternate energy sources in order to minimize the hazardous effects produced by the conventional sources like green house gas emissions, and economically replace the fossil fuels. Various other energy resources are being investigated. These also include the resource generation from solid waste or residue. The solid waste utilized may be municipal solid waste or the agriculture solid waste, or forestry waste also called biomass. These wastes are successfully utilized for the production of biofuels, which include biogas and bio liquids [1],[28],[32],[36].

It is estimated that only agriculture in the world leads to production of over 140 billion metric tons. If properly managed, it can produce huge amounts of energy, approximately equivalent to 50 billion tons of oil. The energy produced from the biomass is not only environment friendly and carbon neutral but it also reduces our dependencies on fossil fuels. Thereby contributes efficiently to energy security and clean climate change mitigations [101].

Biogas production from various types of solid waste and residues like municipal solid waste and agricultural solid waste by anaerobic digestion method has been experimentally investigated and is considered to be one of the best future options available, as it is economically much feasible due to its smaller requirements and using waste or residues as feedstock [11],[27].

This waste has been successfully treated by digesting to form biogas, but this agricultural biomass on one hand contains cellulose and hemicellulose, which are easily digestible and get converted into simple monomers and sugars by digestion, which later converts into biogas. On the other hand it also contains lignocellulose, and the hemicellulose, and cellulose are densely packed by the layers of lignin, which poses as a

*Email: hussainsaleem@uok.edu.pk (Corresponding Author) 


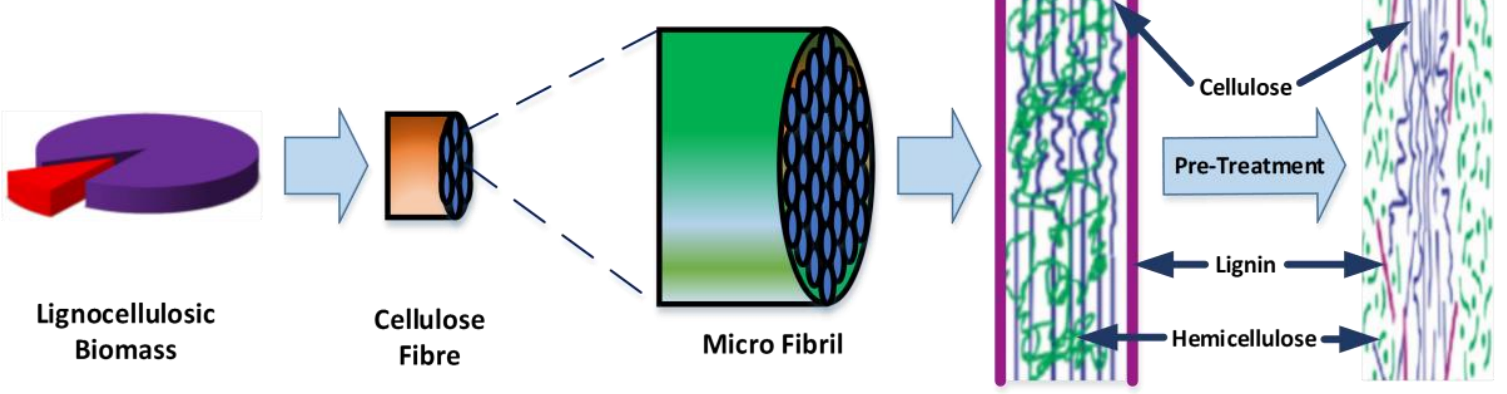

Fig.-1: Pre-Treatment Process of Lignocellulosic Biomass [11]

protective wall of cellulose in plant materials and restricts digestion. So for successful and rapid biodegradation or anaerobic digestion it is necessary to treat lignocellulose, which is called pretreatment. Pretreatment involves the treatment of the lignocellulosic biomass wastes prepared for digestion, which results in delignification, increasing the surface area, porosity, and decreasing the crystallinity of cellulose, hemicellulose and the degree of polymerization. Figure-1 presents a schematic view of pretreatment process [11]. Three pretreatment processes are common:

1. Mechanical or Physical: This treatment involves milling, grinding, irradiation, thermal, hydrothermal, and other physical techniques.

2. Chemical and Physico Chemical: This treatment involves mixing the feedstock with any chemical, or soaking in any chemical solution, like acid, alkali, oxidizing agents, gas treatment, steam explosion, and solvent extraction techniques.

3. Biological Treatments: This treatment involves introducing fungi or/and actinomycetes to the feedstock, which treat the biomass waste biologically [11],[38].

All the treatments are effective to treat lignocellulose, but the percentage or success in treatment varies widely depending upon the method selected. The previous studies have shown that chemical or physico chemical treatment gives the best results in treating the lignocellulose feedstock in comparison to other treatments [38].

Chemical pretreatment involves several treatment techniques, but the most widely studied, and useful regarding lignocellulosic disruption are acid pretreatments, and alkaline pretreatments. The concentrations of the acidic or the alkaline solution vary but in most cases dilute acidic pretreatment and alkaline pretreatments are performed so that it must only be sufficient to disrupt the lignin content. As the higher concentration may cause loss of cellulose and hemicellulose available, which are to be degraded into biofuels [97],[105].

During the acidic and alkaline pretreatment, temperature of the system plays an important role, since the $\mathrm{pH}$ of the system, or the ion activity of acidic and alkaline solutions are affected by temperature. Studies have shown that increasing temperature increases sugar yields and can be useful in decreasing the residence time and acid concentration [2].

The temperature of the system can be increased by conventional techniques, but studies suggest the use of microwave heating rather than conventional heating due to some advantages as compared to conventional heating, like heating by radiation, which causes rapid heating, and enhances chemical activity, selective heating, high temperature capabilities and others [42],[46].

Microwave assisted chemical pretreatments have been performed and have produced successful results to disrupt the recalcitrant structures in lignocellulosic biomass. Microwave treatment has been applied on alkali based pretreatments and acid based pretreatments, and the results were successful in both the cases. It has been assumed that this success of microwave radiation is due to the availability of dielectrics in the biomass, like water, cellulose, hemicellulose, and organic acids [16],[51],[89],[114].

The Objective of this paper is to provide a detailed comparative summary of different microwave pretreatment methods by analyzing them from different aspects. 


\section{LIGNOCELLULOSIC MATERIAL}

Most of the agricultural and forestry residue is composed of lignocellulosic material, this lignocellulosic material has cellulose, hemicellulose and lignin in major quantity and some amounts of pectin, protein and extractives such as sugar, nitrogenous material, chlorophyll, waxes and inorganic material [33],[47],[94],[106]. The lignocellulose substance is considered as essential part of cell walls in the plant biomass, available in solid waste of municipal, forest, crop residues [71],[92].

The composition lignocellulosic biomass varies in terms of species chosen, but the main constituents and their proportions are almost constant like from 50 to $60 \%$ carbohydrates in the form of cellulose and hemicellulose, and around 20 to 35\% lignin [66]. The cellulose in the plants is found in two portions, one is the crystalline or organized structure, while the other is not well organized i.e. in amorphous structure. Cellulose contains subunits of D-glucose, embedded through $\beta-1,4$ glycosidic bonds [33]. Hemicellulose carbohydrate consists of polymers i.e. pentoses, hexoses, and sugar acids. Hemicellulose of hardwood like agricultural plants, straw and grass, contains xylan as major component, while softwood hemicellulose contains glucomannan [33], [85]. Lignin is a most abundant polymer in nature and is present in the plant cellular walls. Basically a heteropolymer comprising of three phenyl propane units (coniferyl, p-coumaryl, and sinapyl alcohol) grouped together via different linkages. The functions of lignin include structural support of plant, resistance against microbial attack, its impermeability and oxidative stress. This is an amorphous heteropolymer, and is non-water soluble (though starts dissolving in water at high temperatures like $180^{\circ} \mathrm{C}$ ) and optically inactive, due to which, its degradation is very tough [33],[63],[64],[65].

\section{BIOFUELS PRODUCTION BY LIGNOCELLULOSIC MATERIAL}

Any energy producing fuel obtained from biomass is termed as biofuels, regardless of its type, weather solid, liquid or gas. Biomass conversion to liquid and gaseous fuels is being preferred nowadays due to some advantages like abundant and easily accessible, non-polluting and environment friendly, sustainable and reliable. Studies have shown that high energy conversion efficiencies could be achieved by using integrated biomass gasification technology, and that could be used for future electricity generation from biomass [22]. Main reasons behind the popularity of biofuels are energy security, environmental concerns, and economics [21].

Depending upon the production technique, biofuels produced from biomass are classified into four groups: (1) First Generation Biofuels (FGBs), (2) Second Generation Biofuels (SGBs), (3) Third Generation Biofuels (TGBs), and (4) Fourth Generation Biofuels. Table-1 presents the classification of Biofuels based on their Production Technologies [32]. In this classification, except third generation biofuels (which are produced from algae or oilgae), all other biofuel types are produced from lignocellulosic biomass. Biofuels produced from organic substances or biomasses by means of contemporary technology are considered as first generation biofuels. These are produced from grains and are converted into starch, and its fermentation producing bioethanol, ultimately pressing them to produce oils and biodiesels. Biofuels of next generation are produced from non-food biomass waste like rice straw, wood and other energy crops. Third generation biofuels are produced from algae, as discussed. While the fourth generation biofuels uses most advanced technology to produce biogasolene from vegetable oil and biodiesel [26].

Table-1: Classification of Biofuels based on their Production Technologies [32]

\begin{tabular}{l|l|l}
\hline \multicolumn{1}{c|}{$\begin{array}{c}\text { Biofuel } \\
\text { Generations }\end{array}$} & \multicolumn{1}{c}{ Feedstock } & \multicolumn{1}{c}{ Example } \\
\hline First Generation & Sugar, Starch, Vegetable Oils, or Animal Fats & Bioalcohols, Vegetable Oil, Biodiesel, Biosyngas, Biogas \\
\hline Second Generation & $\begin{array}{l}\text { Non-Food Crops, Wheat Straw, Corn, Wood, } \\
\text { Solid Waste, Energy Crop }\end{array}$ & $\begin{array}{l}\text { Bioalcohols, Bio-Oil, Bio-DMF, Biohydrogen, BioFischer- } \\
\text { Tropsch Diesel, Wood Diesel }\end{array}$ \\
\hline Third Generation & Algae & Vegetable Oil, Biodiesel \\
\hline Fourth Generation & Vegetable Oil, Biodiesel & Biogasolene \\
\hline
\end{tabular}

Depending upon the type these fuels can be categorized into two main categories like (1) bio-renewable liquid fuels and (2) bio-renewable gaseous fuels. 


\subsection{Liquid Fuels as Bio-Renewables}

Biofuels of liquid nature derived from lignocellulosic biomass are mostly used for transportation, and these fuels are now being focused worldwide due to their availability, sustainability, regional development, rural manufacturing jobs, reduction of greenhouse gas emissions, and its biodegradability [24]. These fuels are further subdivided into these three types: (1) Biodiesels, (2) Bioalcohols, and (3) Biosynthetic Oils.

\subsubsection{Biodiesels or Vegetable Oils}

Biodiesels are the liquid fuels produced from animal fats and vegetable oils, but the production of biodiesel from vegetable oils and cooking oils will cause shortage in edible oils, and are insufficient compared to the demand. Biodiesel has also been studied to be produced from the microbial oils produced from lignocellulosic material and it seems the most suitable economic option for it [18],[43], though research is currently ongoing to improve the pretreatment, saccharification and fermentation of lignocellulosic biomass economically to obtain maximum yield of microbial oil, and as a result maximum biodiesel [106].

\subsubsection{Bioalcohols}

Bioalcohols are the biomethanol and bioethanol production from lignocellulosic biomass which is used for the internal combustion engines as a replacement for gasoline. Biomethanol is produced by gasification of biomass [4]. Bioethanol production is preferred from lignocellulosic material for being low cost material but with ease of its availability [34]. Lignocellulosic biomass contains major percentage of carbohydrate polymers like cellulose and hemicellulose, which are converted into simple sugars by hydrolysis before fermentation, this lignocellulosic hydrolysates contains different amounts of xylose, arabinose, glucose, galactose, mannose, fructose, and rhamnose, which are then fermented into bioethanol by using different microorganisms [96],[106]. Bioethanol is preferred to be used as transportation fuel due to some advantages over biomethanol e.g. use of it alongwith gasoline to make it gasohol does not harm ordinary petrol engines. It is an oxygenated fuel containing $35 \%$ oxygen, and as a result reduces emissions of $\mathrm{NO}_{\mathrm{x}}$ and other particulate matter during combustion. Bioethanol contains high octane number (108) therefore high heats of vaporization, increased flame results in better speeds than gasoline. It means internal combustion engines sustain theoretical efficiencies with above properties of short burn time and high compression ratios against ordinary gasoline as fuel [5],[6].

\subsubsection{Biosynthetic Oils}

Biosynthetic oil as renewable biomass fuel is usually obtained using pyrolysis technique on biomass against low heat of $16 \mathrm{MJ} / \mathrm{kg}$ [10]. Pyrolysis is now considered to be a sound technique to obtain different chemicals and fuels from biomass. In this process, the organic matrix of biomass is thermally decomposed in the absence of oxygen, which results in producing an array of solid, liquid and gaseous products, the obtained products or fuels maybe used in engines and turbines for power generation purposes [7],[104]. Bio oils are produced from techniques of pyrolysis depending upon the operating conditions used, ranging from very slow to fast and flash [25]. Fast pyrolysis is preferred due to higher liquid fuel production [79].

\subsection{Bio-Renewable Gaseous Fuels}

The gaseous fuels obtained from lignocellulosic biomass are the biogas by anaerobic digestion and biohydrogen by anaerobic fermentation.

\subsubsection{Biogas}

Biogas is considered to be most suitable renewable fuel to replace the conventional fossil fuels, in terms of availability, sustainability, reliability, and environmental concerns [88]. Biogas contains a mixture of methane and carbon dioxide with small amount of sulfuric compounds like hydrogen sulfide. A typical composition of biogas includes 55 to $70 \%$ methane, 30 to $45 \%$ carbon dioxide, 0 to $2 \%$ nitrogen, and about 0 to $500 \mathrm{ppm}$ hydrogen sulfide [67]. Methane is the most important product obtained from biogas, to be used as fuel for cooking and transportation purposes. The energy contained in biogas methane is about 4800-6700 $\mathrm{kcal} / \mathrm{m}^{3}$ as compared to pure methane, which contains $8900 \mathrm{kcal} / \mathrm{m}^{3}$ energy [83]. Biogas production becomes maximum when anaerobic digestion method is applied. In this method the organic biomass waste is degraded or biologically transformed by diverse microorganisms, and convert the biomass waste into biogas [53],[54]. The biofuels resulted from the anaerobic digestion can then be utilized as a replacement for fossil fuels, and as these products are carbon neutral so they reduce carbon dioxide emissions to the environment, this process involves 


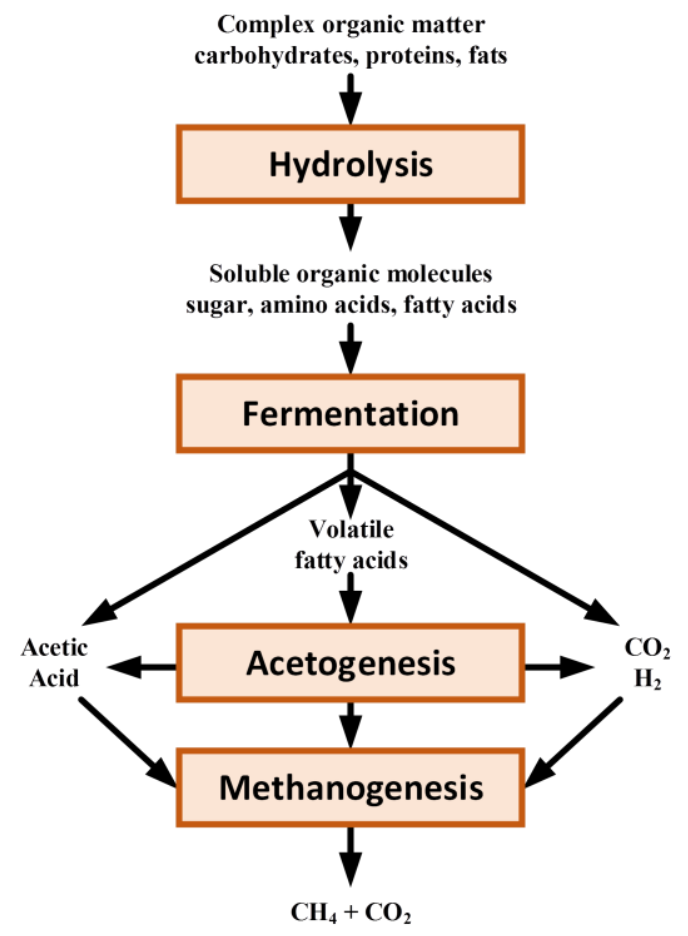

Fig.-2: Anaerobic Digestion Process [109]

four main stages, these are (1) Hydrolysis, (2) Acidogenesis, (3) Acetogenesis, and (4) Methanogenesis [109]. Figure-2 shows the complete process of anaerobic digestion [109].

\subsubsection{Biohydrogen}

Hydrogen production has been under investigation and experimentation since early 1980s and still different techniques are being used and modified to increase its efficiency [68],[69],[115]. One technique is to produce biohydrogen by using anaerobic digestion of different wastes like biomass, MSW, or wastewater sludge, but this process reduces hydrogen production efficiencies after continual use [108]. Biohydrogen as byproduct is released through raw materials which are non-toxic and rich in carbohydrates, processed by photosynthetic natured microorganisms and anaerobics. The process generates organic acids for further methane production [48]. Biohydrogen is also produced by bacterial fermentation of sugars using bacteria such as Clostridia, pH control, temperature, hydraulic retention time (HRT) [8], [23].

\section{PRE-TREATMENT AND ITS TYPES}

As stated earlier lignocellulosic biomass mainly contains polymers of cellulose, hemicellulose, and lignin. The degradation of lignocellulosic biomass into biofuels is limited by a number of factors. The main of which are cellulose crystallinity, moisture content, polymerization rate, lignin content and surface area [13], [52], [55], [78].

In order to overcome these difficulties, and to get the production of biofuels with lesser retention time, pretreatments are applied at the lignocellulosic biomass wastes, many successful pretreatment techniques have been studied, and applied in various methods, these techniques can be broadly classified in three main categories, as Physical or Mechanical, Chemical \& Physico Chemical, and Biological techniques [27],[11].

\subsection{Physical or Mechanical Pretreatment}

The objectives of physical or mechanical pretreatment are to reduce the particle size and crystallinity, increasing the surface area, reducing the degree of polymerization, and shearing the biomass. Achieving these factors increases total hydrolysis yield of lignocellulose, and reduce the digestion time. This treatment method cannot remove lignin, and requires high energy [11],[20],[27],[37]. This treatment is performed by applying one or more of these techniques: 
1. Milling/Grinding (by applying hammer milling, ball milling, two roll milling, colloid milling or vibro milling)

2. Irradiation (by applying Gamma ray, Electron beam, Microwave)

3. Thermal (by the action of temperature, conventional, microwave, hydrothermal)

\subsection{Chemical \& Physico Chemical Pretreatment}

This treatment is performed by introducing one or more chemicals to chemically treat the lignocellulosic biomass. Some of the main techniques used in this treatment are as follows.

\subsubsection{Acidic Pretreatment}

This treatment is performed by adding concentrated or dilute acid in the lignocellulosic biomass for increased anaerobic process of digestion. Objective of this technique is solubilization of hemicellulose resulting in better accessibility to cellulose. This treatment causes the hydrolysis of hemicellulose, which is then subjected to produce HMF, furfural, monomers, and others in acid medium [33],[81]. This method results in increasing the accessible area of cellulose and hemicellulose, partial or nearly complete delignification, decreasing cellulose crystallinity, decreasing rate of polymerization, and partial or complete hemicellulose hydrolysis [27],[11].

\subsubsection{Alkaline Pretreatment}

This treatment is performed by mixing the lignocellulosic biomass with a strong or dilute base, or alkali. This treatment causes saponification and solvation process to elevate the biomass in swollen state, thus making availability of bacteria and enzyme [33]. This method results in increasing delignification process, decreasing cellulose crystallinity, decreasing rate of polymerization, and partial or complete hydrolysis of hemicellulose [27],[11].

\subsubsection{Oxidizing Agents}

This treatment involves addition of an oxidizing compound like hydrogen peroxide, per-acetic, and acid to the lignocellulosic biomass. The objectives of this treatment are the removal of hemicellulose and lignin, with enhancing the availability of cellulose. This method performs treatment of lignocellulosic biomass by various reactions like, electrophilic substitution, displacements of side chains, cleavage of alkyl, aryl ether linkages, or the oxidative cleavage of aromatic nuclei [11],[27],[39].

\subsubsection{Other Chemical Pretreatments}

There are different other chemical pretreatments available such as: (1) Treatment of lignin via solvent extraction process with use of ratios of ethylene-glycol, benzene-water, ethanol-water, butanol-water, and swelling agents, (2) Gas treatment by Chlorine dioxide, Nitrogen dioxide, or Sulphur dioxide, (3) Explosion treatments like seam explosion, ammonia fiber explosion, carbon dioxide explosion, sulfur dioxide explosion [27], [66].

\subsection{Biological Treatments}

This treatment is performed by introducing and mixing of lignocellulosic biomass with one or more of microorganism species like fungi, actinomycetes and others. This method results in delignification, reduction in the rate of cellulose polymerization and hemicellulose hydrolysis partly. The advantages of this process are (1) chemical requirement is zero with lesser energy desires and (2) mild eco system conditions. Disadvantage are very low in above pretreatment processes [27],[56],[84].

\section{MICROWAVE PRETREATMENT}

The effectiveness of any pretreatment of lignocellulosic biomass depends upon three main parameters. These are (1) Chemical or reagent concentration, (2) Retention or residence time, and (3) Temperature. By fluctuating any of these parameters, we can change the hydrolysis rate of lignocellulosic biomass. Studies have shown that the pretreatments performed at high temperature have given successful results, in increasing the hydrolysis rate and product yields, while decreasing the residence time and reagent or chemical concentration required [2],[59],[86],[87]. This temperature increment may be performed by conventional heating or by using microwave radiation, which has some advantages over the conventional heating like, superficial heat transfer, no 


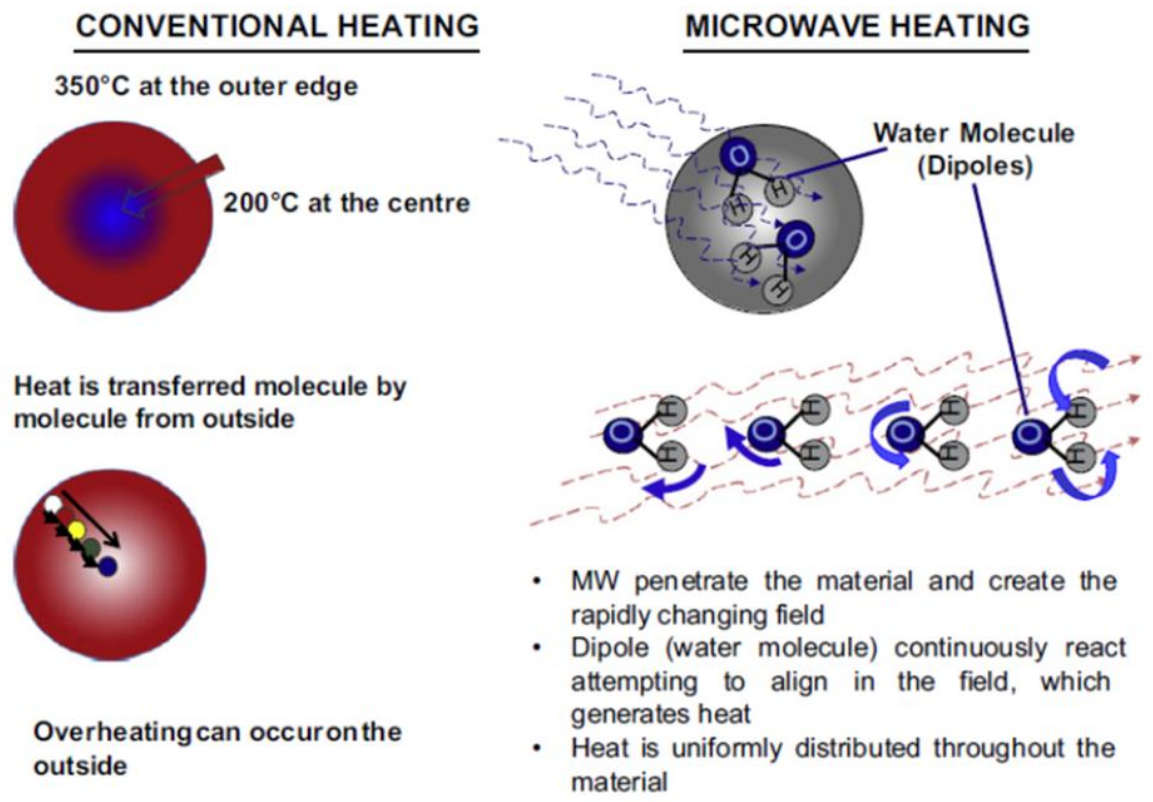

Fig.-3: Difference between conventional Heating and Microwave Heating [100]

direct contact of heating source and material, providing a volumetric and rapid heat and selective heating of more polar part and creating a hot spot with inhomogeneous materials [2],[16],[19],[41],[46],[70],[103]. Figure-3 shows a comparative analysis between conventional heating and microwave heating [100].

Microwaves are the electromagnetic waves between the frequency range of $300 \mathrm{MHz}$ to $300 \mathrm{GHz}$, and mostly the microwave systems available for industrial and domestic purposes use $900 \mathrm{MHz}$ to $2.45 \mathrm{GHz}$ [91]. Figure-4 shows different types of electromagnetic radiations [113]. Microwaves affect the material thermally and non-thermally. Thermally microwaves heat the material by interacting the molecules of material with electromagnetic field produced by microwave energy. Non thermally microwaves affect and interact the polar molecules and ions in the materials, causing physical, chemical, and biological reactions [40],[95],[98],[107].

\section{EFFECTS OF MICROWAVE PRETREATMENT}

Microwave Irradiation effects on biomass and its modification have been studied since 1960's and the modification of barley seeds by microwave treatment was evidenced and reported in 1969 [72]. But it was not until 1980's when the application of microwave irradiation on lignocellulosic biomass for enhanced cellulose saccharification was studied and proven useful in the processing of biofuels [3],[73]. From then the microwave irradiation technique has been used for efficient processing of biofuels and it has since been studied for processing various waste types from sludge and municipal solid waste to biomass solid waste [100].

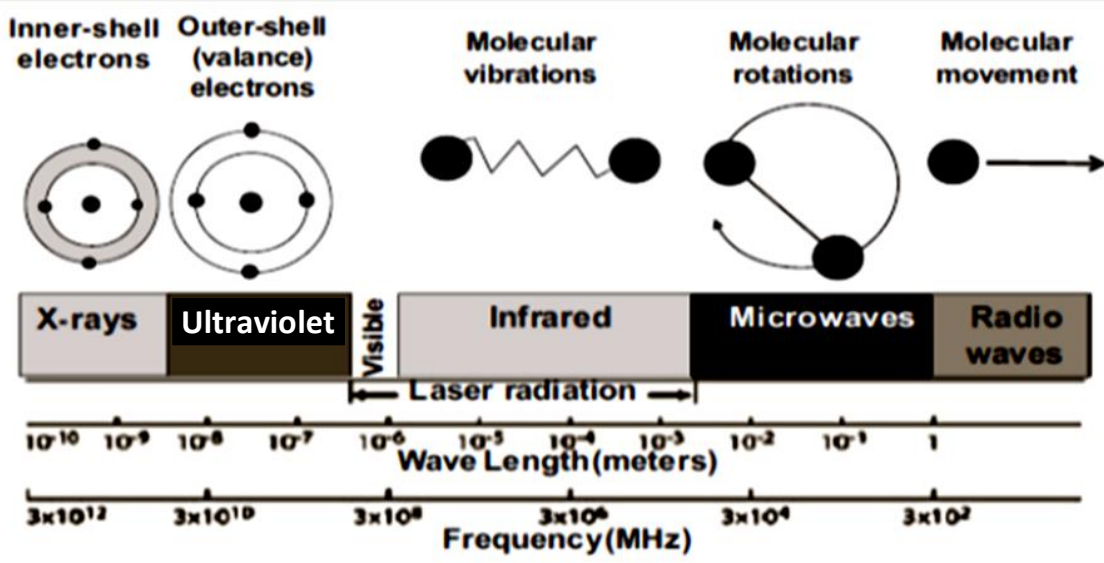

Fig.-4: Types of Electromagnetic Radiations [113] 
Table-2: An example of composition change before and after microwave pretreatment [61]

\begin{tabular}{l|c|c}
\hline \multicolumn{1}{c|}{ Component } & $\begin{array}{c}\text { Before } \\
\text { Pretreatment }\end{array}$ & $\begin{array}{c}\text { After } \\
\text { Pretreatment }\end{array}$ \\
\hline Cellulose & 37 & 42.3 \\
\hline Hemicellulose & 19.6 & 23.6 \\
\hline Klason lignin & 18 & 15.4 \\
\hline Acetyl groups & 3.4 & 2.3 \\
\hline Proteins & 1.5 & 1.4 \\
\hline Extract content & 10.6 & 6.5 \\
\hline Ash & 5.7 & 4.8 \\
\hline Others & 4.2 & 3.7 \\
\hline
\end{tabular}

It has been investigated that the microwave pretreatment technique is very effective in reducing the lignin ratio in biomass, and resulting in an increase in the proportion of cellulose and hemicellulose. An example of composition of biomass (rape-seed) before and after microwave pretreatment is shown in Table-2 [61]. Microwave pretreatment is found to affect the process of anaerobic digestion and biogas production by various parameters [82]. Table-3 shows the main affected parameters reported in the literature [100]. However, the biogas product result of microwave pretreatment of dairy waste activated sludge is shown in Figure-5 [82].

Table-3: Effect of Microwave (MW) Pretreatment on Anaerobic Digestion [100]

\begin{tabular}{|c|c|c|c|}
\hline $\begin{array}{l}\text { Treatment } \\
\text { Conditions }\end{array}$ & Anaerobic Digestion & Findings & Reference \\
\hline $91.2^{\circ} \mathrm{C}, 7 \mathrm{~min}$ & 35 1C, SRT 15 days & $\begin{array}{l}25.9 \% \text { VS reduction, } 23.6 \% \text { TCOD removal } 64 \% \\
\text { and } 79 \% \text { improvement in TCOD removal and in } \\
\text { methane production. Anaerobic digestion of MW } \\
\text { pretreated sludge reduced the reactor SRT from } 15 \\
\text { days to } 8 \text { days }\end{array}$ & [75] \\
\hline $96^{\circ} \mathrm{C}, 3 \% \mathrm{TS}$ & Batch, $33711 \mathrm{C} 5$ day SRT & $\begin{array}{l}30 \% \text { Higher biogas production over control reactor } \\
\text { and } 26 \% \text { higher VS removal }\end{array}$ & [29] \\
\hline $85^{\circ} \mathrm{C}$ & Batch $351 \mathrm{C}, 25$ days SRT & $\begin{array}{l}12 \% \text { and } 16 \% \text { improvement in VS destruction and in } \\
\text { methane production, respectively }\end{array}$ & [49] \\
\hline $175^{\circ} \mathrm{C}, 3 \% \mathrm{TS}$ & Mesophilic batch, 3571 1C & $31 \%$ Higher biogas production than the control & {$[30],[31]$} \\
\hline $170^{\circ} \mathrm{C}, 30 \mathrm{~min}$ & Batch, 35 1C, $30 \mathrm{~d}$ SRT & $\begin{array}{l}25.9 \% \text { Higher biogas production, } 12 \% \text { higher VS } \\
\text { removal over control }\end{array}$ & [80] \\
\hline
\end{tabular}

Microwave pretreatment is very effective in subsequent hydrolysis of biomass, the power and irradiation time has been experimentally investigated and it was analyzed that the rise of irradiation time and power increase the sugar yield [62],[74]. Figure-6 shows the effects of microwave power and irradiation time on the enzymatic hydrolysis yield of sugar [74].

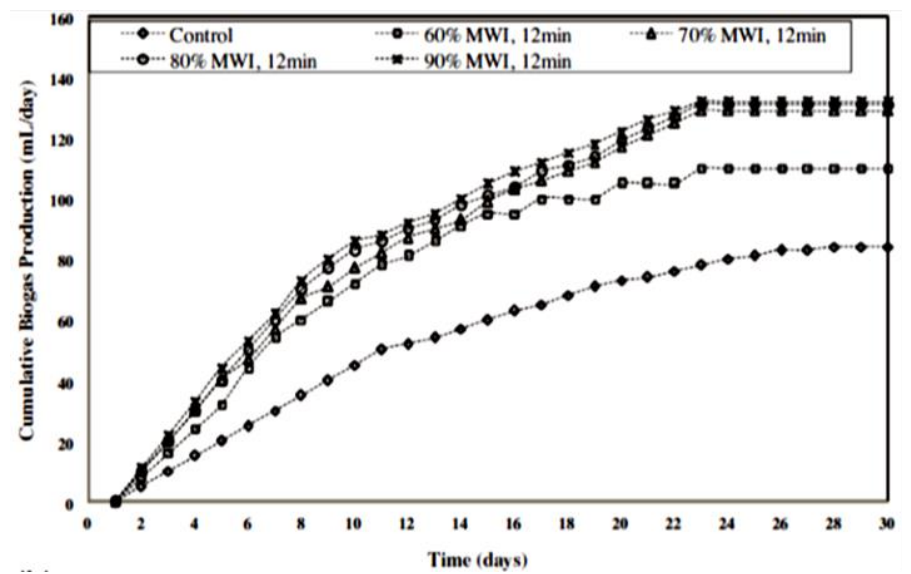

Fig.-5: Biogas production from dairy waste activated sludge by microwave pretreatment [82] 

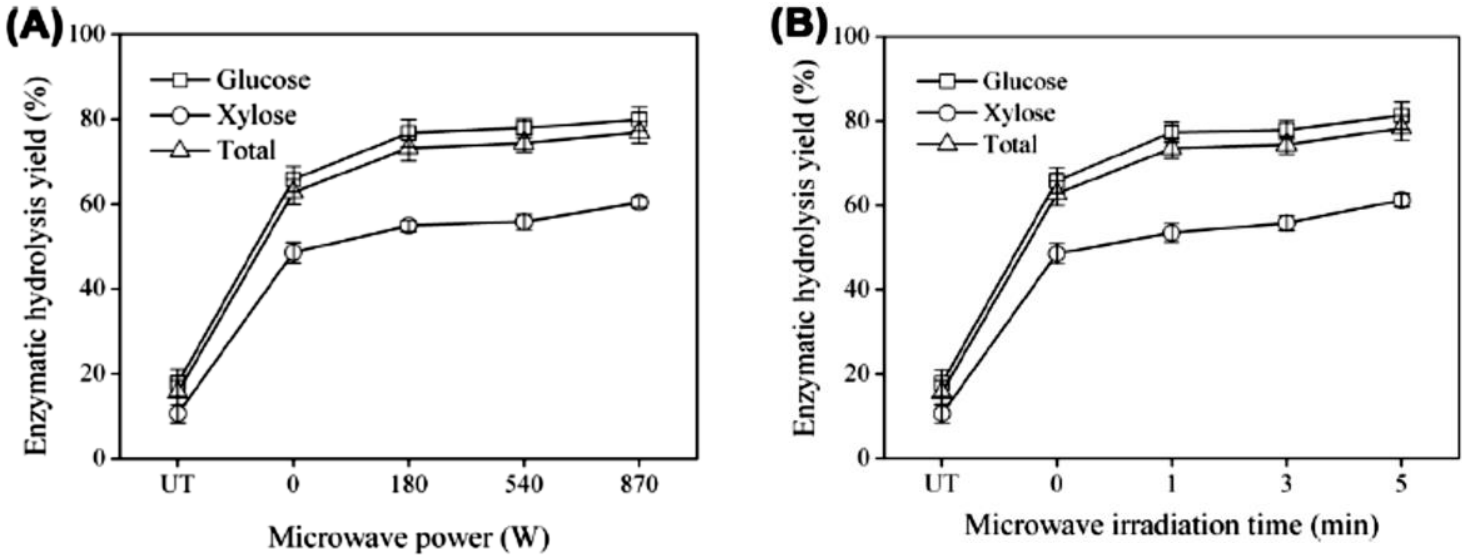

Fig.-6: Effects of Microwave Power and Irradiation time on the Enzymatic Hydrolysis yield of sugar [74]

Passos et. al. investigated the effect of microwave pretreatment on biogas production from wastewater, on various operating power, time and temperature. They found that microwave pretreatment enhanced microalgae solubilization, increased anaerobic digestion rate and improved the methane production potential [76].

Ying Jin et. al. studied the anaerobic digestibility and phosphorus recovery by comparing the conventional heating and microwave heating. They found that microwave heating resulted in more solubilization of lignocellulose than conventional heating, and the anaerobic digestibility and phosphorus recovery were enhanced by using microwave heating [45].

\section{COMBINATION PRETREATMENTS OF MICROWAVE AND THEIR EFFECTS}

Microwave pretreatments are now being used to enhance other pretreatments by using the combination of microwave with other pretreatments. Microwave assisted chemical pretreatments are by far the most common and successful technique in this regard. In this technique the chemical pretreatment technique is enhanced by the assistance of microwave so it is termed as microwave assisted chemical pretreatments. Figure-7 depicts the difference between the result of conventional heating and microwave heating in alkaline environment [17]. Microwave assisted dilute acid pretreatment was studied and it resulted in enhanced recovery of sugar yield by increasing the hydrolysis of hemicellulose from $80 \%$ to $98 \%$ [15]. Microwave assisted alkali technique has also been studied in increasing the saccharification of rice straw and hull [93].

Binod et. al. studied microwave assisted alkali, microwave assisted acidic and microwave assisted $\{$ alkaline + acid $\}$, and found that the maximum sugar yield of upto $0.83 \mathrm{~g} / \mathrm{g}$ biomass was achieved via microwave assisted $\{$ alkaline + acid , followed by microwave alkali resulting in $0.65 \mathrm{~g} / \mathrm{g}$ biomass. However microwave assisted acid pretreatment produced $0.249 \mathrm{~g} / \mathrm{g}$ biomass [9].

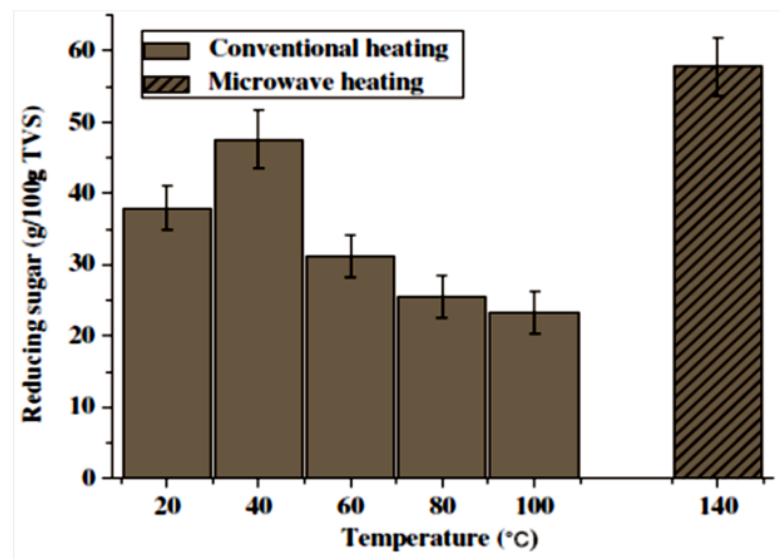

Fig.-7: Difference between Conventional and Microwave Heating in Alkaline Solution [17] 


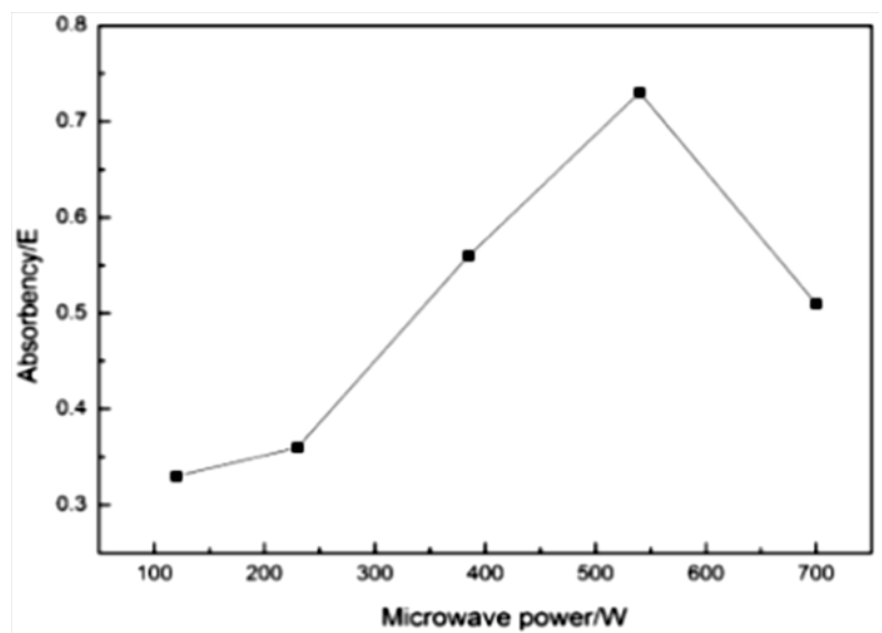

Fig.-8: Influence of MW Power on Lignin Ratio [17]

Chang et. al. investigated the effects of microwave assisted alkali pretreatment for aerobic digestion of sludge, by comparing the individual microwave and alkali pretreated sludge results with microwave assisted alkaline pretreatment and found that microwave assisted alkaline pretreatment resulted in enhanced COD solubilization upto $46 \%$ compared to the additive sum (26.5\%) of individual alkaline (18\%), and Microwave $(8.5 \%)[12]$.

Chen et. al. studied ethanol production from sorghum by microwave assisted dilute ammonia pretreatment, and found that the pretreatment was successful in $48 \%$ removal of lignin with lower ammonia concentration and short reaction time, with producing suitable sugar yield [14]. Figure-8 presents influence of microwave power on lignin ration [17].

Chen et. al. reported that microwave temperature played a critical role in removing hemicellulose from sugarcane bagasse, while performing microwave assisted dilute acid pretreatment. They found that changing the irradiation time produced negligible results at constant concentration of sulphuric acid. Almost all the hemicellulose was removed by the temperature $190^{\circ} \mathrm{C}$ [16]. Table-4 shows some other microwave assisted pretreatments with the operating conditions and their effects.

Table-4: Various Microwave (MW) assisted Pretreatments and Operating Conditions

\begin{tabular}{|c|c|c|c|}
\hline Pretreatment Type & Operating Conditions & Findings & \\
\hline MW assisted Acidic & 0 to $0.02 \mathrm{M}, 180^{\circ} \mathrm{C}$ for $30 \mathrm{Min}$ & 0.02 best concentration, 80 to $98 \%$ hemicellulose hydrolyzed & [15] \\
\hline MW assisted Acidic & $1: 15$ solid to liquid, MW various time & Optimum fermentative hydrogen production & [50] \\
\hline MW assisted Acidic & 0-0.4 N acid, MW $700 \mathrm{~W}, 5-90 \mathrm{~min}$ & Enhanced hydrogen production & [58] \\
\hline MW assisted Alkali & 0 to $5 \%$ concentration, $140^{\circ} \mathrm{C} \mathrm{MW}$ & MW enhanced enzymatic hydrolysis and hydrogen yield & [17] \\
\hline MW assisted Alkali & $0.05-0.3 \mathrm{~g} / \mathrm{g}$ biomass, $70-190^{\circ} \mathrm{C} \mathrm{MW}$ & MW assisted in enzymatic digestibility, and sugar yield & [41] \\
\hline MW assisted Alkali & $2-5 \%$ Alkali, $60-140^{\circ} \mathrm{C} \mathrm{MW}$ & Very effective in extracting $80 \%$ or more hemicellulose & [44] \\
\hline MW assisted Alkali & $1 \%$ alkali, MW 300 to $700 \mathrm{~W}, 15 \mathrm{~min}$ to $2 \mathrm{Hrs}$ & Enhanced enzymatic hydrolysis rate & [111] \\
\hline MW assisted Alkali & $1 \%$ Alkali, MW $700 \mathrm{~W}$ for $25 \mathrm{~min}$ & Optimum ethanol production (64.8\%) obtained & [112] \\
\hline MW assisted Alkaline & $1 \%$ Alkali, MW $120-200^{\circ} \mathrm{C}, 5 \mathrm{~min}$ & Enhanced glucose yield by enzymatic hydrolysis & [99] \\
\hline MW assisted Ball Milling & Ball Milling for 1-6 Hrs, MW 800W, 20 min & Optimum conditions for glucose yield & [77] \\
\hline MW assisted Chemical & $33-117 \mathrm{~g}$ biomass in $62.5 \%$ chemical & Optimum glucose yield by enzymatic hydrolysis & [57] \\
\hline MW assisted Chemical & $50 \mathrm{ml}$ chemical, MW $800 \mathrm{~W}, 5 \mathrm{~min}$ & Optimum conditions for reducing sugar production & [60] \\
\hline MW assisted Chemical & $30 \%$ Chemical, variable MW setting & Optimum conditions for biogas and free liquid fraction & [90] \\
\hline MW assisted Chemical & Various Chemicals, $\mathrm{MW} 80$ to $140^{\circ} \mathrm{C}, 30 \mathrm{~min}$ & High sugar yield $(59.5 \mathrm{C} \%)$ obtained at $140^{\circ} \mathrm{C}$ at $30 \mathrm{~min}$ & [102] \\
\hline MW assisted Chemical & Various Chemicals and settings compared & Most optimum conditions for enzymatic hydrolysis & [110] \\
\hline MW assisted Organic Acid & 1 to $18 \%$ concentration, 100 to $700 \mathrm{~W}$ & Enhanced sugar yield upto $80.08 \%$ & [35] \\
\hline
\end{tabular}




\section{CONCLUSION}

Lignocellulosic Biomass has been used to produce much valuable biofuels, and still being researched to enhance the production of biofuels from it. Pretreatments have played main role in getting optimum production of biofuels. Microwave pretreatments are proving to be successful in treating this lignocellulosic biomass and improving the yield of sugars and biogas from lignocellulosic biomass, this paper has discussed the effects of microwave individual and microwave combined pretreatment on lignocellulosic biomass in terms of biofuels production.

\section{ACKNOWLEDGEMENTS}

Authors sincerely acknowledge the financial, equipment and moral support of Universiti Teknologi Petronas, Tronoh, Perak, Malaysia. The authors also appreciate the efforts of Quaid-e-Awam University of Engineering, Science \& Technology together with Institute of Advanced Research Studies in Chemical Sciences (IARSCS), University of Sindh, Jamshoro, Pakistan. The authors are also thankful to Incharge Softronix Science Simulation Lab (FF-21, UBIT Building), Department of Computer Science, University of Karachi, Pakistan for providing support for document manuscript processing of this Research paper.

\section{REFERENCES}

[1] AK Shah, ZM Ali, AR Memon, AJ Laghari, MA Mughal, SFA Shah, Hussain Saleem. Exploitation of Low Cost Coal Fly Ash Adsorbent with Coagulants for the Treatment of Industrial Complex Nature Dyes Wastewater, International Journal of Scientific \& Engineering Research, Volume 4, Issue 9, (September-2013).

[2] Arthur P. Redding, Ziyu Wang, Deepak R. Keshwani, Jay J. Cheng, High temperature dilute acid pretreatment of coastal Bermuda grass for enzymatic hydrolysis, Bioresource Technology, Volume 102, Issue 2, January (2011), Pages 1415-1424.

[3] Azuma, J., Higashino, J., Asai, T., Koshijima, T., (1985). Microwave irradiation of lignocellulosic materials: IV. Enhancement of enzymatic susceptibility of microwave-irradiated softwoods. Wood Res. 71, 13-24.

[4] Balat M, Balat M, Kirtay E, Balat H. Main routes for the thermo-conversion of biomass into fuels and chemicals. Part 2: gasification systems. Energy Convers Manage (2009); 50:3158-68.

[5] Balat M. Bioethanol as a vehicular fuel: a critical review. Energy Sources A (2009); 31:1242-55.

[6] Balat M. Global bio-fuel processing and production trends. Energy Explore Exploit (2007); 25:195-218.

[7] Balat M. Mechanisms of thermochemical biomass conversion processes. Part 1: reactions of pyrolysis. Energy Sources A (2008); 30:620-35.

[8] Balat M. Production of hydrogen via biological processes. Energy Sources A (2009); 31:1802-12.

[9] Binod P., K. Satyanagalakshmi, R. Sindhu, K. U. Janu, R. K. Sukumaran, and A. Pandey, Short duration microwave assisted pretreatment enhances the enzymatic saccharification and fermentable sugar yield from sugarcane bagasse, Renewable Energy, vol. 37, no. 1, pp. 109-116, Jan. (2012).

[10] Brammer JG, Lauer M, Bridgwater AV. Opportunities for biomass-derived "bio-oil”" in European heat and power markets. Energy Policy (2006);34:2871-80.

[11] Chandra R., Takeuchi H., Hasegawa T., Methane Production from Lignocellulosic Agricultural Crop Wastes: A Review in context to Second Generation of Biofuel Production, Renewable and Sustainable Energy Reviews, Volume 16, Issue 3, April (2012), Pages 1462-1476.

[12] Chang C.-J., V. K. Tyagi, and S.-L. Lo, Effects of microwave and alkali induced pretreatment on sludge solubilization and subsequent aerobic digestion., Bio-Resource technology, vol. 102, no. 17, pp. 7633-40, Sep. (2011)

[13] Chang, V.S., Holtzapple, M.T., (2000). Fundamental factors affecting enzymatic reactivity. Appl. Biochem. Biotechnol., 5 37.

[14] Chen C., D. Boldor, G. Aita, and M. Walker, Ethanol production from sorghum by a microwave-assisted dilute ammonia pretreatment., Bioresource technology, vol. 110, pp. 190-7, Apr. (2012).

[15] Chen W.-H., S.-C. Ye, and H.-K. Sheen, Hydrolysis characteristics of sugarcane bagasse pretreated by dilute acid solution in a microwave irradiation environment, Applied Energy, vol. 93, pp. 237-244, May (2012).

[16] Chen W.-H., Y.-J. Tu, and H.-K. Sheen, Disruption of Sugarcane Bagasse Lignocellulosic Structure by means of Dilute Sulfuric Acid Pretreatment with Microwave-Assisted Heating, Applied Energy, vol. 88, no. 8, pp. 2726-2734, Aug. (2011).

[17] Cheng J., H. Su, J. Zhou, W. Song, and K. Cen, Microwave-assisted alkali pretreatment of rice straw to promote enzymatic hydrolysis and hydrogen production in dark- and photo-fermentation, International Journal of Hydrogen Energy, vol. 36, no. 3, pp. 2093-2101, Feb. (2011).

[18] Dai, C., Tao, J., Xie, F., Dai, Y., Zhao, M., (2007). Biodiesel generation from oleaginous yeast Rhodotorula glutinis with xylose assimilating capacity. Afr. J. Biotechnol. 6, 2130-2134.

[19] De La Hoz A., A. Diaz-Ortiz, A. Moreno, Microwaves in organic synthesis. Thermal and non- thermal microwave effects, Chem. Soc. Rev. 34 (2) (2005)164-178.

[20] Delgenés, J.P., Penaud, V., Moletta, R., (2002). Pretreatments for the enhancement of anaerobic digestion of solid wastes Chapter 8. In: Biomethanization of the Organic Fraction of Municipal Solid Wastes. IWA Publishing, pp. 201-228. 
[21] Demirbas A, Dincer K. Sustainable green diesel: a futuristic view. Energy Sources A (2008); 30:1233-41

[22] Demirbas A. Biofuels securing the planet's future energy needs. Energy Convers Manage (2009); 50:2239-49.

[23] Demirbas A. Biohydrogen generation from organic waste. Energy Sources A (2008); 30:475-82

[24] Demirbas A. Biorefineries: current activities and future developments. Energy Convers Manage (2009); 50:2782-801.

[25] Demirbas A. Fuel properties of pyrolysis oils from biomass. Energy Sources A (2009); 31:412-9.

[26] Demirbas MF. Biorefineries for biofuel upgrading: a critical review. Appl Energy (2009); 86:S151-61.

[27] Escamilla-Alvarado C., Esparza-García F., Ríos-Leal E., Hernandez-Vera R., Ponce-Noyola M.T., Poggi-Varaldo H.M., Gas Biofuels from Solid Substrate Hydrogenogenic-Methanogenic Fermentation of the Organic Fraction of Municipal Solid Waste, Journal of Biotechnology, Volume 150, (2010), Pages 13-14.

[28] Escamilla-Alvarado C., Ríos-Leal E., Ponce-Noyola M.T., Poggi-Varaldo H.M., Gas Biofuels from Solid Substrate Hydrogenogenic-Methanogenic Fermentation of the Organic Fraction of Municipal Solid Waste, Process Biochemistry, Volume 47, Issue 11, (2012), Pages 1572-1587.

[29] Eskicioglu C, Droste RL, Kennedy KJ. Performance of anaerobic waste activated sludge digesters after MW pretreatment. Water Environment Research (2007); 79(11):2265-73.

[30] Eskicioglu C, Kennedy KJ, Droste RL. Enhanced disinfection and methane production from sewage sludge by microwave irradiation. Desalination (2009); 248:279-85.

[31] Eskicioglu C, Kennedy KJ, Droste RL. Initial examination of MW pretreat- ment on primary, secondary and mixed sludges before and after anaerobic digestion. Water Science and Technology (2008); 57(3):311-7.

[32] Fatih D, Mustafa B, Havva B, Biowastes-to-Biofuels, Energy Conversion and Management, Volume 52, Issue 4, (2011), pp.1815-1828.

[33] Fengel, D., Wegener, G., (1984). Wood: Chemistry, Ultrastructure, Reactions. De Gruyter, Berlin.

[34] Gnansounou E, Bedniaguine D, Dauriat A. Promoting bioethanol production through clean development mechanism: findings and lessons learnt from ASIATIC project. In: Proceedings of the 7th IAEE European energy conference, Bergen, Norway; Aug, (2005).

[35] Gong G., D. Liu, and Y. Huang, Microwave-assisted organic acid pretreatment for enzymatic hydrolysis of rice straw, Biosystems Engineering, vol. 107, no. 2, pp. 67-73, Oct. (2010).

[36] Hahn-Hagerdal, B., Galbe, M., Gorwa-Grauslund, M.F., Liden, G., Zacchi, G., Bio-Ethanol - The Fuel of Tomorrow from the Residues of Today. Trends Biotechnol. (2006), 24, 549-556.

[37] Hartmann, H., Angelidaki, I., Ahring, B.K., (1999). Increase of anaerobic degradation of particulate organic matter in fullscale biogas plants by mechanical maceration.In: Mata-Alvarez, J., Tilche, A., Cecchi, F. (Eds), Proceedings of the Second International Symposium on Anaerobic Digestion of Solid Wastes, Barcelona,vol. 1, pp 129-136.

[38] Hendriks A.W.T.M., G. Zeeman, Pretreatments to Enhance the Digestibility of Lignocellulosic Biomass, Bioresource Technology, Volume 100, Issue 1, January (2009), Pages 10-18.

[39] Hon, D.N.S., Shiraishi, N., (2001). Wood and Cellulosic Chemistry, second ed. Dekker, New York.

[40] Hong SM, Park JK, Lee YO. Mechanisms of MW irradiation involved in the destruction of fecal coliforms from biosolids. Water Research (2004); 38(6): 1615-25.

[41] Hu Z. and Z. Wen, Enhancing enzymatic digestibility of switch grass by microwave-assisted alkali pretreatment, Biochemical Engineering Journal, vol. 38, no. 3, pp. 369-378, Mar. (2008).

[42] Huan Ma, Wei-Wei Liu, Xing Chen, Yue-Jin Wu, Zeng-Liang Yu, Enhanced Enzymatic Saccharification of Rice Straw by Microwave Pretreatment, Bioresource Technology, Volume 100, Issue 3, February (2009), Pages 1279-1284.

[43] Huang, C., Zong, M., Wu, H., Liu, Q., (2009). Microbial oil production from rice straw hydrolysate by Trichosporon fermentans. Bioresource. Technol. 100, 4535-4538.

[44] Janker-Obermeier I., V. Sieber, M. Faulstich, and D. Schieder, Solubilization of hemicellulose and lignin from wheat straw through microwave-assisted alkali treatment, Industrial Crops and Products, vol. 39, pp. 198-203, Sep. (2012).

[45] Jin Y., Z. Hu, and Z. Wen, Enhancing anaerobic digestibility and phosphorus recovery of dairy manure through microwavebased thermochemical pretreatment., Water research, vol. 43, no. 14, pp. 3493-502, Aug. (2009).

[46] Jones D.A., T.P. Lelyveld, S.D. Mavrofidis, S.W. Kingman, N.J. Miles, Microwave Heating Applications in Environmental Engineering - A Review, Resources, Conservation and Recycling, Volume 34, Issue 2, January (2002), Pages 75-90.

[47] Jorgensen H, Kristensen JB, Felby C. Enzymatic conversion of lignocellulose into fermentable sugars: challenges and opportunities. Journal of Biofuels, Bioproducts \& Biorefining (2007);1(2):119-34.

[48] Kapdan IK, Kargi F. Bio-hydrogen production from waste materials. Enzyme Microb Technol (2006); 38:569-82.

[49] Kennedy KJ, Thibault G, Droste RL. MW enhanced digestion of aerobic SBR sludge. Water SA (2007); 33(2):261-70.

[50] Khamtib S., P. Plangklang, and A. Reungsang, Optimization of fermentative hydrogen production from hydrolysate of microwave assisted sulfuric acid pretreated oil palm trunk by hot spring enriched culture, International Journal of Hydrogen Energy, vol. 36, no. 21, pp. 14204-14216, Oct. (2011).

[51] Kitchaiya, P., Intanakul, P., Krairish, M., (2003). Enhancement of enzymatic hydrolysis of lignocellulosic wastes by microwave pretreatment under atmospheric pressure. J. Wood Chem. Technol. 23, 217-225

[52] Koullas, D.P., Christakopoulos, P., Kekos, D., Macris, B.J., Koukios, E.G., (1992). Correlating the effect of pretreatment on the enzymatic hydrolysis of straw. Biotechnol. Bioeng. 39, 113-116.

[53] Lastella, G., Testa, C., Cornacchia, G., Notornicola, M., Voltasio, F., Sharma, V.K., (2002). Anaerbic digestion of semi-solid organic waste: biogas production and its purification. Energy Conserv. Manage. 43, 63-75. 
[54] Lata, K., Rajeshwari, K.V., Pant, D.C., Kishore, V.V.N., (2002). Volatile fatty acid production during anaerobic mesophilic digestion of tea and vegetable market wastes. W. J. Microbiol. Biotechnol. 18, 589-592.

[55] Laureano-Perez, L., Teymouri, F., Alizadeh, H., Dale, B.E., (2005). Understanding factors that limit enzymatic hydrolysis of biomass. Appl. Biochem. Biotechnol., 1081-1099.

[56] Lee J. Biological conversion of lignocellulosic biomass to ethanol. J Biotechnol (1997); 56(1):1-24.

[57] Li H. and J. Xu, Optimization of microwave-assisted calcium chloride pretreatment of corn stover., Bioresource technology, vol. 127, pp. 112-8, Jan. (2013).

[58] Liu C. and X. Cheng, Improved hydrogen production via thermophilic fermentation of corn stover by microwave-assisted acid pretreatment, International Journal of Hydrogen Energy, vol. 35, no. 17, pp. 8945-8952, Sep. (2010).

[59] Lloyd, T., Wyman, C., (2005). Combined sugar yields for combined dilute acid pretreatment of corn stover followed by enzymatic hydrolysis of the remaining solids. Bioresour. Technol. 96, 1967- 1977.

[60] Lü J. and P. Zhou, Optimization of microwave-assisted $\mathrm{FeCl} 3$ pretreatment conditions of rice straw and utilization of Trichoderma viride and Bacillus pumilus for production of reducing sugars., Bioresource technology, vol. 102, no. 13, pp. 6966-71, Jul. (2011).

[61] Lu X., B. Xi, Y. Zhang, and I. Angelidaki, Bioresource Technology Microwave pretreatment of rape straw for bioethanol production : Focus on energy efficiency, vol. 102, pp. 7937-7940, (2011).

[62] Ma H., W.-W. Liu, X. Chen, Y.-J. Wu, and Z.-L. Yu, Enhanced enzymatic saccharification of rice straw by microwave pretreatment., Bioresource technology, vol. 100, no. 3, pp. 1279-84, Feb. (2009).

[63] MA Mughal, AH Mughal, ZM Ali, GZ Memon, MY Khuhawar, Hussain Saleem. New Antimicrobial Schiff base Polymers derived from 6, 6-Methylenebis (1-Napthaldehyde), International Journal of Scientific \& Engineering Research, Volume 4, Issue 9, (September-2013).

[64] MA Mughal, AH Mughal, ZM Ali, GZ Memon, MY Khuhawar, Hussain Saleem. Synthesis, Characterization and Antibacterial and Antifungal Studies of Schiff base Polymers derived from Methylene bis Cinnamaldehyde. IOSR Journal of Engineering (IOSRJEN), Vol. 3, Issue 10 (October 2013), pp.48-55.

[65] MA Mughal, AH Mughal, ZM Ali, Hussain Saleem. Antimicrobial Viscometric Studies of Thermally Stable Metal based Schiff Base Polymer derived from 4, 4-Methylene Bis Furfuraldehyde. International Journal of Advancements in Research \& Technology, Volume 2, Issue 8, (August-2013).

[66] Mats Galbe, Guido Zacchi, Pretreatment: The key to efficient utilization of lignocellulosic materials, biomass and bio energy 46 (2012) 70--78.

[67] Monnet F. An introduction to anaerobic digestion of organic wastes. A report by Remade Scotland; November, (2003). http://www.bioenergywm.org/ documents/Anaerobic

[68] Morinaga T, Kawada N. The production of acetic acid from carbon dioxide and hydrogen by an anaerobic bacterium. J Biotechnol (1990); 14:187-94.

[69] Nandi R, Sengupta S. Microbial production of hydrogen — an overview. Crit Rev Microbiol (1998); 24:61-84.

[70] Nüchter, M., Müller, U., Ondruschka, B., Tied, A., Lautenschläger, W., (2003). Microwave-assisted chemical reactions. Chem. Eng. Technol. 26 (12), 1207-1216.

[71] Oliveira LS, Franca AS. From solid biowastes to liquid biofuels. In: Ashworth GS, Azevedo P, editors. Agricultural wastes. Hauppauge (NY, USA): Nova Science Publishers Inc.; (2009).

[72] Om P. Kamra, P.C. Kesavan, (1969). Modification of barley seed radiosensitivity with microwave radiation. Radiation Botany, Volume 9, Issue 6, 1969, Pages 443-448.

[73] Ooshima, H., Aso, K., Harano, Y., Yamamoto, T., (1984). Microwave treatment of cellulosic materials for their enzymatichydrolysis. Biotechnol. Lett. 6, 289-294.

[74] Pang F., S. Xue, S. Yu, C. Zhang, B. Li, and Y. Kang, Effects of microwave power and microwave irradiation time on pretreatment efficiency and characteristics of corn stover using combination of steam explosion and microwave irradiation (SE-MI) pretreatment., Bioresource technology, vol. 118, pp. 111-9, Aug. (2012).

[75] Park B, Ahn J, Kim J, Hwang S. Use of MW pretreatment for enhanced anaerobiosis of secondary sludge. Water Science and Technology (2004); 50(9): 17-23

[76] Passos F., M. Solé, J. García, and I. Ferrer, Biogas production from microalgae grown in wastewater: Effect of microwave pretreatment, Applied Energy, vol. 108, pp. 168-175, (2013).

[77] Peng H., H. Li, H. Luo, and J. Xu, A novel combined pretreatment of ball milling and microwave irradiation for enhancing enzymatic hydrolysis of microcrystalline cellulose., Bioresource technology, vol. 130, pp. 81-7, Feb. (2013).

[78] Puri, V.P., (1984). Effect of crystallinity and degree of polymerization of cellulose on enzymatic saccharification. Biotechnol. Bioeng. 26, 1219-1222.

[79] Pütün AE. Biomass to bio-oil via fast pyrolysis of cotton straw and stalk. Energy Sources (2002); 24:275-85.

[80] Qiao W, Wang W, Zhu CP, Zhang ZZ. Biogas recovery from MW heated sludge by anaerobic digestion. Science ChinaTechnological Sciences (2010); 53(1):144-9.

[81] Ramos, L.P., (2003). The chemistry involved in the steam treatment of lignocellulosic materials. Quim. Nova. 26 (6), $863-$ 871.

[82] Rani R. U., S. A. Kumar, S. Kaliappan, I. Yeom, and J. R. Banu, Impacts of microwave pretreatments on the semi-continuous anaerobic digestion of dairy waste activated sludge, Waste Management, vol. 33, no. 5, pp. 1119-1127, (2013). 
[83] Rasi S, Veijanen A, Rintala J. Trace compounds of biogas from different biogas production plants. Energy (2007); 32:137580.

[84] Ray MJ, Leak DJ, Spanu PD, Murphy RJ. Brown rot fungal early stage decay mechanism as a biological pretreatment for softwood biomass in biofuel production. Biomass Bioenergy (2010); 34(8):1257e62.

[85] Saha, B.C., (2003). Hemicellulose bioconversion. J. Ind. Microbiol. Biotechnol. 30, 279-291.

[86] Saha, B.C., Biswas, A., Cotta, M.A., (2008). Microwave pretreatment, enzymatic saccharification and fermentation of wheat straw to ethanol. J. BiobasedMater.Bioenergy 2 (3), 210-217.

[87] Saha, B.C., Iten, L.B., Cotta, M.A., Wu, Y.V., (2005). Dilute acid pretreatment, enzymatic saccharification and fermentation of wheat straw to ethanol. Process Biochem. 40 (12), 3693-3700.

[88] Santosh Y, Sreekrishnan TR, Kohli S, Rana V. Enhancement of biogas production from solid substrates using different techniques-a review. Bioresour Technol (2004); 95:1-10.

[89] Sapci Z., The effect of microwave pretreatment on biogas production from agricultural straws., Bioresource technology, vol. 128, pp. 487-94, Jan. (2013). [16]

[90] Shahriari H., M. Warith, M. Hamoda, and K. J. Kennedy, Anaerobic digestion of organic fraction of municipal solid waste combining two pretreatment modalities, high temperature microwave and hydrogen peroxide., Waste management (New York, N.Y.), vol. 32, no. 1, pp. 41-52, Jan. (2012).

[91] Shi, J., Pu, Y.Q., Yang, B., Ragauskas, A.J., Wyman, C.E., (2011). Comparison of microwaves to fluidized sand baths for heating tubular reactors for hydrothermal and dilute acid batch pretreatment of corn stover. Bioresour. Technol. 102, 59525961.

[92] Sims R. Biomass and resources bioenergy options for a cleaner environment in developed and developing countries. London: Elsevier Science; (2003).

[93] Singh A., S. Tuteja, N. Singh, and N. R. Bishnoi, Enhanced saccharification of rice straw and hull by microwave-alkali pretreatment and lignocellulolytic enzyme production., Bioresource technology, vol. 102, no. 2, pp. 1773-82, Jan. (2011).

[94] Sjöström E. Wood chemistry: fundamentals and applications. San Diego, USA: Academic Press; (1993).

[95] Sridar, V., (1998). Microwave radiation as a catalyst for chemical reactions. Curr. Sci. 74, 446-450.

[96] Taherzadeh MJ, Karimi K. Acid-based hydrolysis processes for ethanol from lignocellulosic materials: a review. Bio Resources (2007); 2:472-99.

[97] Teng-Chieh Hsu, Gia-Luen Guo, Wen-Hua Chen, Wen-Song Hwang, Effect of Dilute Acid Pretreatment of Rice Straw on Structural Properties and Enzymatic Hydrolysis, Bioresource Technology, Volume 101, Issue 13, July (2010), Pages $4907-$ 4913.

[98] Thostenson, E.T., Chou, T.W., (1999). Microwave processing: fundamentals and applications. Composites Part A: Appl. Sci. Manuf. 30, 1055-1071.

[99] Tsubaki S. and J. Azuma, Total fractionation of green tea residue by microwave-assisted alkaline pretreatment and enzymatic hydrolysis., Bioresource technology, vol. 131, pp. 485-91, Mar. (2013).

[100] Tyagi V. K. and S.-L. Lo, Microwave irradiation: A sustainable way for sludge treatment and resource recovery, Renewable and Sustainable Energy Reviews, vol. 18, no. 71, pp. 288-305, Feb. (2013).

[101] UNEP. Converting Agriculture Biomass into a Resource. (2009).

[102] Verma P., T. Watanabe, Y. Honda, and T. Watanabe, Microwave-assisted pretreatment of woody biomass with ammonium molybdate activated by H2O2., Bioresource technology, vol. 102, no. 4, pp. 3941-5, Feb. (2011).

[103] Xu, F., Jiang, J.-X., Sun, R.-C., She, D., Peng, B., Sun, J.-X., Kennedy, J.F., (2008). Rapid esterification of wheat straw hemicelluloses induced by microwave irradiation. Carbohydr. Polym. 73 (4), 612-620.

[104] Yaman S. Pyrolysis of biomass to produce fuels and chemical feedstocks. Energy Convers Manage (2004); 45:651-71.

[105] Yong Cheol Park, Jun Seok Kim, Comparison of Various Alkaline Pretreatment Methods of Lignocellulosic Biomass, Energy, Volume 47, Issue 1, November (2012), Pages 31-35.

[106] Yousuf A., Biodiesel from lignocellulosic biomass--prospects and challenges., Waste management (New York, N.Y.), vol. 32, no. 11, pp. 2061-7, Nov. (2012).

[107] Yu Y, Chan WI, Liao PH, Lo KV. Disinfection and solubilization of sewage sludge using the microwave enhanced advanced oxidation process. Journal of Hazardous Materials (2010); 181:1143-7.

[108] Zheng H, O’Sullivan C, Mereddy R, Zeng RJ, Duke M, Clarke W. Production of bio-hydrogen using a membrane anaerobic reactor: limitations due to diffusion. In: Proceedings of the environmental research event (2009), Noosa Heads, Queensland, Australia; May 10-13, 2009.

[109] Zheng Y, Pan Z, Zhang R, El-Mashad HM, Pan J, Jenkins BM. Anaerobic digestion of saline creeping wild ryegrass for biogas production and pretreatment of particleboard material. Bioresour Technol (2009); 100:1582-8.

[110] Zhu S., Y. Wu, Z. Yu, C. Wang, F. Yu, S. Jin, Y. Ding, R. Chi, J. Liao, and Y. Zhang, Comparison of Three Microwave/Chemical Pretreatment Processes for Enzymatic Hydrolysis of Rice Straw, Biosystems Engineering, vol. 93, no. 3, pp. 279-283, Mar. (2006).

[111] Zhu S., Y. Wu, Z. Yu, J. Liao, and Y. Zhang, Pretreatment by microwave/alkali of rice straw and its enzymic hydrolysis, Process Biochemistry, vol. 40, no. 9, pp. 3082-3086, Sep. (2005).

[112] Zhu S., Y. Wu, Z. Yu, X. Zhang, C. Wang, F. Yu, and S. Jin, Production of ethanol from microwave-assisted alkali pretreated wheat straw, Process Biochemistry, vol. 41, no. 4, pp. 869-873, Apr. (2006). 
[113] Zlotorzynski A. The application of microwave radiation to analytical and environmental chemistry. Critical Reviews in Analytical Chemistry (1995); 25(1): 43-76.

[114] ZM Ali, MA Mughal, AJ Laghari, AK Ansari, Hussain Saleem. Polymeric Cellulose Derivative: Carboxymethyl-Cellulose as useful Organic Flocculant against Industrial Waste Waters, International Journal of Advancements in Research \& Technology, Volume 2, Issue 8, (August-2013).

[115] Zoetmeyer J, Matthijsen AJCM, Van Den Heuvel JC, Cohen A, Boelhouwer C. Anaerobic acidification of glucose in an upflow reactor. Biomass (1982); 2:187-99.

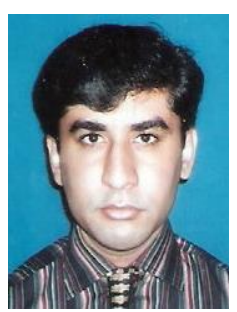

Shuaib Muhammad Laghari is currently a Postgraduate research student of Environmental Engineering at University Teknologi Petronas, Tronoh, Perak, Malaysia since January 2013. He has served as Lecturer at Energy \& Environmental Engineering Department, Quaid-e-Awam University of Engineering, Science, \& Technology, Nawabshah, Sindh, Pakistan, from 18th January 2012 to 4th January 2013. He did his Bachelor of Engineering (Petroleum \& Natural Gas Engineering) from Mehran University of Engineering \& Technology, Jamshoro, Sindh, Pakistan.

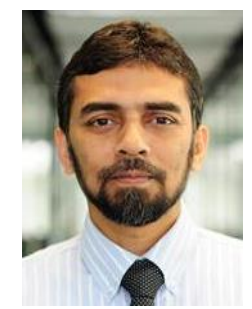

Mohamed Hasnain Isa received Ph.D. in Environmental Engg. from The University of Newcastle upon Tyne, England in 1998. He obtained B.Sc. (Civil Engg.) and M.Sc. (Environmental \& Water Resources Engg.) degrees from The Aligarh Muslim University, India. Dr. Hasnain started his career in 1989 as a Lecturer at The Aligarh Muslim University, India. He also worked as Senior Environmental Consultant in Hong Kong and as Lecturer at The Universiti Sains Malaysia, Malaysia. He is currently an Associate Professor at the Universiti Teknologi Petronas, Malaysia. Dr. Hasnain has given invited talks on many occasions to practicing engineers. He has been involved in a number of research projects on wastewater treatment using biological i.e. Aerobic \& Anaerobic and Physico-Chemical i.e. Adsorption, Coagulation, Advanced, Oxidation, and Electrochemical methods, and on Solid Waste Management. He has published over 160 scientific papers in international journals and conferences. He is member of various national and international professional bodies. He also serves as peer reviewer for several national and international journals.

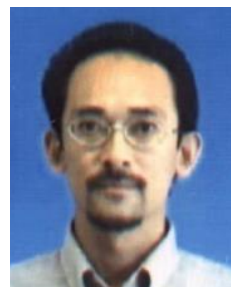

Mohd Azmuddin bin Abdullah did his PhD in Bioprocess Engineering from University of Putra Malaysia. He did his Master of Engineering in Chemical Engineering and Biotechnology from University of Manchester, Institute of Science and Technology (UMIST), United Kingdom. He was nominated for inclusion in International Profiles of the Accomplished Leaders, American Biographical Institute in December 2010. He got Best Paper Award for Article "Mechanical Properties of Polymer Composite from Oil Palm Empty Fruit Bunches Extracted Cellulose", in National Symposium on Polymeric Materials, 3-5 $5^{\text {th }}$ October 2012, Universiti Sains Malaysia . He awarded Gold Medal and Best Presentation for project on "Biomethane and Biohydrogen Production by Microalgal Treatment of Palm Oil Mill Effluent" SEDEX28, 10-11 $1^{\text {th }}$ August 2011, Universiti Teknologi Petronas.

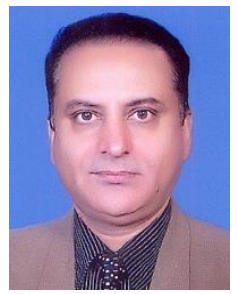

Abdul Jabbar Laghari is presently working as Director (Incharge) of Institute of Advanced Research Studies in Chemical Sciences (IARSCS) / HRL, University of Sindh, Jamshoro, Pakistan and ExOfficio of Dr. M. A. Kazi Institute of Chemistry, University of Sindh, Jamshoro, Pakistan. He has teaching experience of 17 plus years. He is Ph.D. and worked extensively on the development of new mixed stationary phases for gas chromatography and gas chromatographic determination of metal ions. $\mathrm{He}$ is author of various research articles.

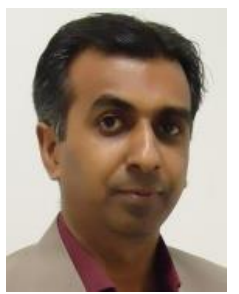

Hussain Saleem is Assistant Professor bearing vast experience of more than 17 years of University Teaching, Administration and Research in various dimensions of Computer Science at Department of Computer Science, University of Karachi, Pakistan exclusively serving the University from last more than one decade i.e. 13 years approx. He received B.S. in Electronics Engineering from Sir Syed University of Engineering \& Technology, Karachi in 1997 and has done Masters in Computer Science from University of Karachi in 2001. He also received Diploma in Statistics from University of Karachi in 2007. He has completed his work for doctoral degree Ph.D. in Computer Science. Mr. Hussain is Reviewer of various International Journals globally and has published more than 32 Research Papers in International Journals of repute. Mr. Hussain is a good speaker and has been invited as guest in TV programs and disseminated knowledge over latest technology trends. He is senior member of PEC (Pakistan Engineering Council), IEEE, ACM, IACSIT, and SDIWC. 